\title{
POGGE'S ACCOUNT OF GLOBAL POVERTY AND RESPONSES FROM ELEMENTARY TEACHERS
}

\author{
NIÑOVAL F. PACAOL*
}

\begin{abstract}
It is the overriding objective of international organizations and some intellectuals to provide practical ways in solving the issue of global poverty. From a philosophical reading towards a qualitative design, this paper aims to answer the question of obligation among affluent countries and its people for the eradication of worldwide poverty as posed by some moral and political theorists. The research hinges on the guide and approach of Thomas Pogge's account of Global Poverty. Then, using the descriptive method, the paper bridges the gap of a global issue to the fringes of local perspectives as it affects education and knowledge-production. Elementary teachers served as the participants of the study to gather responses concerning global perspectives on the issue. The following themes reflect the teachers' responses: 1) prevalence of inequalities, 2) socioeconomic gain from discriminatory advantage, 3) creation of social problems, 4) quality of living as indication of progress, and 5) 'we are in the same world'.
\end{abstract}

Keywords: Global poverty; Obligation; Global order; Pogge; Elementary teachers

\section{INTRODUCTION}

Global poverty is often associated with injustice and human rights. Donald and Mottershaw (2009) state that "communities experiencing poverty use human rights to act against injustice." If human rights are violated as a form of injustice, it is usually the case that the poor are affected. During the last half of the $20^{\text {th }}$ century, various world organizations and First World countries face criticism from notable speakers and scholars for causing worldwide poverty. The claim is quite provocative since common orientation holds that rich nations charitably give and donate some of their wealth to poor states to eradicate and solve the problem of poverty. Nonetheless, the economic anthropologist and specialist Hickel (2018), in his commentary regarding the study conducted by US-based Global Financial Integrity and the Centre for Applied Research at the Norwegian School of Economics, stipulated that the outflow of money from Global South is severely great compared to the financial aid of Global North, thus, poor countries are, in reality, developing the rich countries and not the other way around. In simple terms, though developing countries received some assistance (i.e. aid, investment), they also sent trillions of dollars to the rest of the world. The outflow of money, according to Hickel, most likely comes to pass through the international trade system. One of the notable critics of this issue is Thomas Pogge, a professor of philosophy and international affairs. In Real World Justice: Grounds, Principles, Human Rights, and Social Institutions, Pogge (2005) questioned the global international order by saying that it was only created for the promotion of special interest which creates an inequality of poverty. He explicitly argued that: 
The affluent countries and their citizens are then implicated in world poverty in two ways. We are implicated, first, because our great privileges and advantage as well as their extreme poverty and disadvantage have emerged through one historical process that was pervaded by unimaginable crimes. To be sure, we bear absolutely no moral responsibility for these crimes, even if we are direct descendants of people who do. Still, we are at fault for continuing to enforce the extreme inequalities that emerged in the course of that deeply unjust historical process. Secondly and independently, we are implicated because we are using our economic, technological, and military advantages to impose a global institutional order that is manifestly and grievously unjust... By imposing this grievously unjust global order upon the rest of the world, the affluent countries, in collaboration with the so-called elites of the developing countries, are harming the global poor - to put it mildly. To put it less mildly, the imposition of this global order constitutes the largest (though not the gravest) crime against humanity ever committed. (Pogge 2005, 333-4).

The critique of Pogge of the global order is rooted in the notion that world poverty amounts to the largest human rights violation in human history and challenging the system is the practical thing to do to alleviate the lives of millions of deprived individuals. Peirik (2016) strongly agrees with Pogge as he declared that "the current global institutional order might contribute substantially to global poverty and human rights violation" (608). Thus, as an adverse exchange, affluent people giving some of their money causes the poor to be worst-off and establishes great inequalities instead. Previously, ten conditions have been advanced by Pogge as a complete depiction of radical inequalities and prevalence of global poverty:

(1.) The worse-off are very badly off in absolute terms; (2.) They are also very badly off in relative terms - very much worse off than many others; (3.) The inequality is impervious: it is difficult or impossible for the worse-off substantially to improve their lot: and most of the better-off never experience life at the bottom for even a few months and have no vivid idea of what it is like to live in that way; (4.) The inequality is pervasive: it concerns not merely some aspects of life such as the climate or access to natural beauty or high culture but most aspects or all; (5.) The inequality is avoidable: the better-off can improve the circumstances of the worse-off without becoming badly off themselves; (6.) There is a shared institutional order that is shaped by the better-off and imposed on the worse-off; (7.) This institutional order is implicated in the reproduction of radical inequality in that there is a feasible institutional alternative under which such severe and extensive poverty would not persist; (8.) The radical inequality cannot be traced to extra-social factors (such as genetic handicaps or natural disasters) which as such, affect different human beings differentially; (9.) The better-off enjoy significant advantages in the use of a single natural resource base from whose benefits the worse-off are largely and without compensation excluded; and (10.) The social starting positions of the worse-off and the better-off have emerged from a single historical process that was pervaded by massive grievous wrongs. (Pogge 2002, 198-9; 202-3).

Education is likewise affected by these series of inequalities. When severe poverty strikes a Third World nation, schools, teachers, and children are compromised for quality learning and instruction (Palmer 2014). Furthermore, Chossudovsky (2020) decried some of the influential global institutions including the World Bank for causing the increased levels of poverty throughout the developing world. He maintained that the education sector of a nation experiences severe cuts in its spending as a result of the strict "structural adjustment programs" of the World Bank. The programs follow as a condition for receiving loans which would have a direct impact on teachers' wages like with Vietnam's case on the post-world war period (Chossudovsky 2003). The entire educational system of a country encounters profound problems due to the existing injustice and world order. Despite these, the ideals of education encourage poverty reduction, require educators and educational leaders to be knowledgeable, develop a global perspective on the causes of poverty and injustices, and must work with other agents and broader society that promote socio-economic and political reforms leading to a more sustainable world and respecting human rights (Parrett and Budge 2015; Steiner 1996). Therefore, a socially just response must work within and outside the schools (Flessa 2007 as cited in CTF 2009).

Global awareness and perspectives are important for teachers and schools who are considered to be part of unravelling the necessary solution. In a 2010 focus group research of 
British Columbia Teachers' Federation (BCTF) which focuses on teachers' perspectives about poverty and education issues, teachers acknowledge the significant role of social-justice advocacy in providing awareness on the issue and addressing the main causes of it. Education here serves as the operant viability to bridge the gap of addressing global issues through pedagogical considerations. Elementary teachers, in particular, can factor in perspectives that can ripple through in global formulations. Identically, Vongalis (2004) delved into the significant role of teachers for poverty reduction concentrating on the concerns expressed by national teachers' unions from Global North-South countries (including some elementary teachers' associations) during, for instance, the 2001 Third World Congress in Thailand. For less developed countries, teachers together with other actors should act against the neo-liberal reform (e.g. unfair educational policies from international organizations like the World Bank and OECD) that creates inequity in society. Chilean educators, for example, strongly accentuated that "in the education sector, teachers need to rethink the role they are to play. Professional teaching staff must be a human resource to combat for the rights of people" (Vongalis 2004, 493). Even African countries attested the negative impact of neo-liberal change (international organizations' policies) on society as it increases the rate of child labour. Although educators from Global North demonstrate unanimity with Global South teachers' resistance from the policies of international agencies which contravened with their aims for equitable working conditions and compliance to international standards, they were ambivalent between "reproducing a system that was part of the broader global capital competitive model or letting their students down by not giving them the competitive edge" (Vongalis 2004, 496). We could say from this framework that citizens (e.g. teachers) of affluent nations are participating in an unjust global order. Philippines is among the disadvantaged global actors a globally categorized Global South and developing country (Valencia 2018; FCSSC n.d.), a nation seeking to be socially and economically advanced yet its progress is much slower (Lasco et al. 2009).

Exploring the causes as well as the alternative solution for poverty is a question of responsibility as viewed by Pogge. The Global North must resolve poverty in collaboration with international bodies. Consequently, the paper examines such issues by looking into the knowledge of teachers from the Philippines, which belong to the Global South, concerning the bases of the obligation of the richest countries. Understanding the teachers' insights about the study would be significant since their being part of the school community plays a vital role in instituting changes in education and knowledge-production, especially in shaping the minds of the future generation. With an interdisciplinary view in mind, the research problem is situated on Pogge's account of Global Poverty to take on the elementary teachers from the Philippines concerning their insights of the bases affluent countries' and their citizens' obligation to global poverty.

\section{Thomas Pogge's Account of Global Poverty}

Global poverty and disparity between rich and poor are self-evident and one of the subjects of various debates among thinkers (e.g. moral philosophers, philanthropists, national leaders, political theorists) of the 20th century in dealing with social issues. For many, affluent countries as well as its people must be in the front line in addressing the problem of worldwide lack of adequate resources for developing countries. Some philosophers including Thomas Pogge presented a moral perspective about the problem. In his theory, Pogge established the distinction of positive and negative duties as the central tenet of his argument concerning inequality and injustice. On the one hand, positive duty assigns an obligation to someone to provide any assistance to worse-off people. On the other hand, negative duty requires each one to avoid imposing suffering and harm to others. 
When someone violates the rights of others, compensation is needed. However, in the case of positive duty, harming others and then appeasing them does not count as assistance (Sonderholm 2012). Despite Pogge's introduction of two types of duty, his argument on solving the problem of worldwide poverty in developing countries focuses on the idea of negative duty since, according to him, the affluent public from rich countries causes the suffering of the global poor through the violation of their human rights and inaccessibility of necessities. The overriding approach of Pogge on the issue is through the application of the institutional method in identifying who are the responsible agents of poverty.

Institutional approach, in Pogge's point of view concerning global poverty, is the persistence of different agencies and organizations that create and enforce global order which worsens the lives of the global poor. Some actors for the prevalence of poverty include supranational bodies (e.g. EU, IMF, WB, and UN), multinational corporations, and nongovernmental organizations that are parties together with other states. They create policies that ground for the extraction of resources which worsens the poverty scale of the global poor. In other words, the considerable features of the existing global order "tend to benefit the governments, corporations, and citizens of the rich countries and the political-military elites of the poor countries at the expense of the vast majority of those living in the poor countries" (Pogge 2007, 51). Such examples are 1) the borrowing resource privilege of a country's leader from international organizations to stay longer in their position and its lack of transparency; and 2) trade policies of the World Trade Organization that impose barriers on developing countries to export their products (Sonderholm 2012).

This prevailing development among developed countries and international actors led Pogge to conclude that it is as if citizens of rich nations are obligated and imbued with a duty to harm and violate the rights of the global poor. For Abumere (2012), this obligation must point to institutional reform that must be initiated by the citizens of developed countries. This must happen so that the citizens can knowingly participate in calling out the system that defiles negative duty. Kriegstein (2009) states that "citizens of the rich countries, by silently cooperating in an unjust global order, are violating weighty duties towards the global poor, and those duties are significantly more weighty than they are usually taken to be" (67). We must weigh up the consequences of our actions because by indirectly participating with the global order we are harming the poor and underprivileged. For Devetak et al. (2017) the obligation to aid the worse-off member of the human race is under the elimination of inequalities and promotion of equality. So, the creation of international order should ensure that everyone particularly the less fortunate (worldwide and within each nation) - must have access to the basic needs and material resources. Redistribution of wealth and resources among rich and poor people must take place (Dietzel 2018). Consequently, Geirdner (2009) stressed out the importance of the theory as a necessary means to motivate the affluent nations and various actors of global order to create and promote a just institutional policy to evade the violation of human rights of the impoverished human person. Global poverty is indeed a form of injustice that must be a social concern since it relentlessly restrains the ability of people to live an ethical life. Some moral agents, through their participation with the existing global order, hinder other people to express and attain their needs (Nwaneri 2017).

In the case of the Philippines, on account of the unjust global order imposed by international bodies, the country's economic condition is getting worse. This allows for the existence Filipino domestic migrant workers (FDMWs) working abroad to sustain the needs of their families (Urbano 2011). But for those who cannot afford to work internationally and whose lives are in the verge of severe poverty, Dalberis (2015) says that there is a strong correlation between poverty and crime and although inequalities do not have a strong connection on nations' number of transgressions, it could trigger and lead to some social problems like violence. Hence, poverty, as a consequence of defiling the negative duty of rich 
countries, may result in certain social problems committed by the global poor to support their domestic needs.

Historical colonization also counts as an infringement of negative duty: "historically, imperial and colonial nations have a special responsibility to alleviate the inequality caused by their exploitative endeavours" (Khalil 2018, 25). The exploitation of natural resources and encroachment to the colonies' politics by the Global North gives them the power to flourish their own countries while the colonized world or the Global South pay for the cost and are still struggling from the abuses and manipulation from the past. Although the acts were made a long time ago, the fact that the current population of historically colonial and imperial democratic liberal nations is still benefitting and choosing not to make some compensation can be held morally responsible. Pogge (2005) invoked the effects of historical violence:

The present world is characterized not only by radical inequality as defined, but also by the fact that "the social starting positions of the worse-off and the better-off have emerged from a single historical process that was pervaded by massive grievous wrongs"... Most of the existing international inequality in standards of living was built up in the colonial period when today's affluent countries ruled today's poor regions of the world: trading their people like cattle, destroying their political institutions and cultures, and taking their natural resources. (38).

The global application of Pogge's institutional approach and the framework describing negative duty is certainly a helpful way in looking at these problems and may seem to be a strong argument; nonetheless, its main precept was challenged by some theorists and authors. For Daskal (2013), talking about reform is broad and unclear, and if we ought to uphold and believe that negative duty in the more stringent principle of obligation, we should first identify its limits. Instead of the total alteration of the system, a natural solution to approach the unjust institutional order is to "adopt a policy that restricted the resource and borrowing privileges to regimes that meet some standards of democracy or domestic accountability" (389). Parcon (2017) questions the approach not as a total dead end but its limitation in presenting a comprehensive theory on global poverty that is responsive and realistic. In his critical evaluation of Pogge's concept of negative duty, he illustrated that the philosopher's approach is simply a strategy to meet the criterion of feasibility (or wide audience approval) and the theory's incompleteness is clear by not putting some focus on positive duty as a compliment for a complete theory. He also added that Pogge disregards the interactional aspect that could count for the causes of poverty that his institutional approach cannot. However, Boot (2014) in his radical view argued that negative responsibility is a reflection of imperfect duty that is not enforceable. And unlike perfect duty which has a corresponding right to coerce and considered to be a duty of justice, the duty 'not to harm' does not have the features of the former, thus categorized as a duty of virtue. In basic terms, despite the arguments that affluent people do have an obligation to aid the global poor, it cannot be described as something that can be enforced on someone.

Weidel (2012) made as well a saddle shift in understanding responsibility. Despite recognizing and being sympathetic with Pogge's claim that Western citizens are active in the impoverishment of people in the world, he saw it unsatisfactory due to its incapableness of answering some questions such as: If people in rich countries cease violating the rights of the poor, will this end global poverty? According to him, the question of poverty is not only a matter of doing something to 'them' [global poor] but also to 'us' [humanity]. Hampering our duty and obligations towards others, we are dehumanizing ourselves and our sense of humanity. In other words, in responding to global poverty we are trying to make a fully human world whose impulse presents neediness and interdependence to help the persons who are in need.

Though Pogge's approach in tackling poverty face some vagueness and deficit, Spauwen (2012) believes that it has more bearing in reality and society in which we live 
primarily due to its pragmatic characteristic. Negative duty, for Pertiwi (2018), should be the ethical guidance of today's politics which is neglected in the world of 'might is right'. While its moral application is still doubtful for many, it offers hope for the restructuring of the international system and acceptance of affluent countries to alleviate the poorest people's suffering (like hunger and malnutrition). To de-emphasize the nature of duty is, in some ways, useful, however, to claim that the negative duty as less stringent is a premature belief. The breadth and depth of treatable suffering caused by poverty leaves no room for doubt and involves a considerable change in our habits and actions (Lichtenberg 2010). The whole gamut of global enterprise starts with educating the young, so that elementary teachers within pedagogical institutions can in some sense acquire the necessary reformulation of mindsets to the reality of global poverty, both from the wider and immediate framework.

\section{METHODS}

Following from Pogge's account, this research made use of a qualitative research strategy where there are no statistical or numerical data gathered. A qualitative design was used by the researcher to understand someone's beliefs, experiences, and attitudes. Such research design is sometimes described as humanistic and idealistic. Henceforth, it offers in-depth information from the perspective of the participants about specific topics (Pathak et al. 2013; Hall et al. 2018). In particular, the type of qualitative design used by the researcher was a descriptive approach. According to Bradshaw et al. (2017), the qualitative descriptive design seeks to discover and understand a phenomenon, a process, or the perspective and worldviews of people. Under the descriptive approach, the researcher is active in the research process as he talks directly to the participants and data is subjective since each person has their perspective and each perspective counts. In this study, the researcher wanted to understand and get the global perspectives and viewpoints of the participants regarding their insights of the bases affluent countries' and their citizens' obligation to global poverty.

This study was conducted at Barcelona Elementary School in Sta. Rita, Samar, Philippines. The institution is a multi-grade school that consists of five teachers- one kindergarten teacher, one teacher for Grade 1 and 2, one teacher for Grade 3 and 4, one teacher for Grade 5 and 6, and one teacher-in-charge. The participants were three elementary teachers in a school of Sta. Rita III District of Samar Division. In particular, the participants were teaching Grade 1 to 6 pupils. The researcher chose the said participants because as educators they experienced the direct and indirect implications of poverty in their assigned community. Also, Samar is one of the poorest provinces in the country (Quejada and Orale 2018). Through the involvement of the participants in the study, it could provide some insights into the global awareness and perspectives of teachers who include poverty and its solutions in their teachings (Flynn 2014).

In determining the participants of the study, the researcher used a non-probability sampling called convenience sampling. Due to the researcher's address and location, the study used such kind of sampling technique since the target participants met certain standards including easy accessibility, geographical proximity, and availability at any given time. One advantage of using convenience sampling is the idea that members (which will be the participants) of the target group are homogenous and there will be no farfetched results compared to other samples like random sampling (Etikan et al. 2016). Acknowledging that "there is no one-size-fits-all method to reach data saturation" (Fusch and Ness 2015), the participants' number are justified, seeing that they are more than half of the total population and they fit perfectly the sampling used. Among the five teachers - which is an indication of how poverty affects the distribution of educational means - the three participants were the only 
elementary teachers and are the more qualified in relaying their responses in terms of their qualifications of completing graduate studies and their understanding of poverty in context. Reflexibility, at this point, is mitigated by a partial introduction of the concepts and most importantly, the constant clarifications on the participants' end, allowing for further processing of their subjective responses that eventually make up the thematization process.

As instrument, the researcher employed a semi-structured interview as the data collection instrument. The interview questions were aimed at inquiring about relevant information on the idea of obligation in responding to global poverty. A semi-structured interview was used to gather in-depth information from the participants through an open-ended question. According to Jamshed (2014), such kind of interview is conducted once only with an individual or in this case some selected teachers.

After selecting and finalizing the necessary research instrument (a semi-structured interview) as well as the interview guide, the researcher visited the school where the study will be conducted and personally ask prior permission from the teacher-in-charge by presenting an authorization letter to conduct a study to collect the necessary data. Afterward, the researcher briefly discussed the nature of the study with the teacher-in-charge together with the intended number of participants who will undertake the study. Without any hesitation, a good rapport and consent with the teacher-in-charge of the school were established for the research. Moreover, a copy of the authorization letter was presented to the participants for them to be informed about the nature of the research and also for the legality. The researcher recorded the entire interview to verify the data effectively and they were also informed that their responses and personal information will remain confidential and anonymous (unless requested accordingly).

In interpreting the data from the interview, thematic analysis was used by the researcher. For Neuendorf (2019), thematic analysis is a qualitative study in drawing out themes through an inductive approach derived from the interview and helps developed a new interpretation of the problem. Specifically, Braun and Clarke's (2006) six-phase framework for doing a thematic analysis was carefully applied, namely: 1) become familiar with the data; 2) generate initial codes; 3) search for themes; 4) review themes; 5) define themes; and 6) writeup. Thus, this analysis provides and highlights the main group of meanings from the findings.

\section{RESULTS}

\section{Finding}

Based on the responses of the participants, it was a unanimous view that global poverty is a worldwide issue in which people who are living under this category are experiencing lack of quality access with their necessities including food, clothing, and shelter. This actuality led them [the participants] to conclude that talking about global poverty must be a 'social concern' and 'obligation' for those affluent people of rich countries to help and support the global poor and which includes the indigents in the country.

The interview further revealed that the idea of obligation is due to the presence of inequalities in society and also because global poverty poses some social, environmental, and other human problems. Aiding the global poor means that we are inclined to improving their lives as we see consider the current status of them as unfortunate. Nonetheless, the participants further argued that aid and help must not only take the form of money or cash but must also encompasses manpower, giving pieces of advice in free and accessible platforms, and sharing one's experiences with them on how to alleviate their lives from poverty. The idea of 'social concern' and 'obligation' as viewed by the participants must not necessary be a donation rather 
as means to dismantle structures that warrant poverty. So, the problem of poverty was disclosed as not a matter of personal choice since everyone is affected and must take action towards it.

Analysis

Employing thematic analysis in the study, negative duty (not to inflict harm) emerged to be the foundation of the obligation of affluent nations in solving and reducing the clutches of poverty. The following themes were identified as the bases and forms of negative responsibility: prevalence of inequalities, socioeconomic gain from discriminatory advantage, creation of social problems, quality of living as indication of progress, and 'we are in the same world'. These themes should be treated as distinct yet interconnected from each other.

\section{Prevalence of Inequalities}

Responding to global poverty comes down and derives from the presence of inequalities in society. Economic and social inequalities are in some ways products of poor distribution of wealth and resources. Some other cases are due to the self-interest and egotism of government leaders and organizations who made international orders only for their benefit and advantage. This poor distribution is considered to be a violation of an individual's rights for equal access to resources. For the participants, these are unfair for those poor people who suffer the result. Inequality, therefore, is viewed to be contrary to the common view that the social and economic status of the poor is just a normal case in which they are unfortunate to have enough money and resources to sustain their needs.

\section{Socioeconomic Gain from Discriminatory Advantage}

Due to the unfair and unequal creation of agreements and laws among nations and organizations, affluent countries experience a prosperous and booming phase in their lives. The well-off populace experiencing a better form of living ought to help those who are not. Participants claimed that it should be the obligation of the Global North to extend their hands and give some of the resources to Global South. Doing this sort kind of action are some of the avenues to help them, and for the affluent group of people giving away some of their money is just a little bit part of their entire earnings so the concept is viable. The interview underlined the notion that it would be wrong not to help and enjoy one's life with the amount of money that one has given the fact that there are a lot of people currently deprived of necessities and would probably die due to lack of access.

\section{Creation of Social Problems}

Global poverty has many derivatives from the inequitable treatment of developed countries. It creates numerous problems not only of society but of the world. It creates ecological, social, and educational problems. Along these lines, structures that create these problems encounter more specific ones such as climate change, violence, unemployment, and illiteracy. These things seem to have no connection with other people, however, they cause indirect implications or consequences in the world which exacerbate the suffering and living of the poor. To be exact, poverty, as a result of inequalities and unjust order, generates a chain effect. Because of unemployment, for example, humans are forced to commit terrible acts and illegal activities just to sustain and support their needs and feed some of the members of the family. Hence, as one of the participants puts it, global poverty is a real problem that affects millions of people 
around the world. To end these from spreading, aiding these people is the key to improve their lives and stop them from doing such things.

\section{Quality of Living as an Indication of Progress}

One of the indications of social progress is the state of living of every citizen in a certain nation. So even if the minority of the people are affluent while the rest and the majority are poor, that is no evidence to call it progress. Every government and worldwide organization aims to promote equality and equity in every aspect but the fact that they prioritize their interest, affluent countries do have an obligation to do more by make these goals become a reality in pragmatic terms. One way to do this, according to the participants, is by educating the people about establishing a livelihood that is in demand in the society where they live. Policies and programs must ensure that there are available resources that can provide long term advantages to the people.

\section{We are in the Same World}

As humans, we are living in the same world and breathe the same air. This reality gives support with the idea that every person who are living in a much better life or the affluent people must show some care towards their fellow humans and promote the common good of everyone. This, according to the participants, connect to the cost of their violation of negative duty through the better-off people actively promoting and implementing a corrupt global order created for a selected few and private individuals. The concept of obligation for other people must be manifestly observed for no one will help us but only ourselves as animals with higher ways of thinking capacity and with emotions that can feel the suffering and others' state of living. Based on the interview, to be human, therefore, is to empathize with the problem of one's fellow human species who are also occupying the same planet.

\section{Interpretation}

The research findings and analysis broke some of our common views on the causes and obligations for global poverty. It opens for a complex understanding of various international bodies that we usually consider to be helping the Global South or developing countries for socio-economic and political stability. The absence of global response may worsen the lived experiences of impoverished people and could tolerate the prevailing unfair worldwide policy. The essentiality for justice, in this context, can be broadened and the aspiration now for the eradication of poverty is not only within the state. Legal and moral accountability and culpability must transpire since the ubiquitousness of poverty would not essentially degenerate if it had not a venal global order constructed by the political elites of developed countries alongside the numerous international bodies. The issue's crux (encompassing poverty, injustice, and human rights) is to have a "universal sense of belonging" which reflects teachers' dispositions as caring and empathetic individuals based on the participants' responses. To see global poverty as an issue which requires justice and immediate response from the Global North implies the need to look for others' situation and be sensitive and susceptible to the minute and immense acts that directly and circuitously harm the global poor in their own contexts. 


\section{DISCUSSION}

Global poverty is manifestly a piercing social and moral issue that needs attention globally. Several people arguably state that the issue is a matter of agreement, plan, cooperation, and steadfast solution. However, the answer is still vague and the division of liabilities is not welldefined. Since poor people themselves are incapable of relieving their lives, debate and argument for who will be held accountable and legally responsible are being opened to the public square for thorough discussion and examination. Consequently, the researcher tried to answer the question through this study. It was an acknowledged perspective of the participants that obligation towards the global poor is distinctly embedded in the hands of affluent countries and its people based on violating their duty not to cause harm and suffering to the global poor or Global South. As participant C puts it, "kaangayan la nga it rikuhanon nga mga nasod in bumulig ha mga pobre kay tungod nga hira it kadak-an nga nanalumpigos hit mga pobre nga nasod pinaagi hit ira impluwensya ngan diri patas nga mga pulisiya" [rich countries are indebted to the global poor since they constitute most of the domination towards the poor countries through their influence and unequal policies]. This obligation is clearly expressed in Thomas Pogge's theory of global poverty especially in his notion of negative duty; alternatively, in the participants' own words, such obligation can also be called a "social concern" which encourages someone to be mindful with their unwarranted acts. Consequently, developed nations must take the first step in questioning these practices from a moral perspective and realize that helping the poor is needed. This development encourages an exchange of action that would guarantee the welfare and safety of the global poor as an emolument for the inequalities and human rights violations made by the undue institutional order.

The obligation is more likely linked to various types of inequalities. International organizations, for instance, create unfair policies in economic trade that favour only their side. By "upholding trade policies that allow for these phenomena, the relevant political institutions are actively preventing members of the global poor from reaping the important economic benefits that follow in the wake of doing trade with relatively affluent countries" (Sonderholm 2012, 389). Such tremendous order and policies are violations of the human rights of people in dire indigence. Economic job is affected which obstructs people's capacity to attain their survival needs and the actuality of Filipino domestic migrant works is a reflection of this injustice (Urbano 2011). And if we look deeply into the interior case of a country, several people suffer considering the "borrowing resource privilege" of a poor country's political leader (Sonderholm 2012). Participant A has been critical about this:

\footnotetext{
"Tungod hit international nga balaud nga pwede umutang it lider hit usa nga nasod ha mga international bank para supurtahan it mga panginahanglanon hini, danay nagiging rason pa ini para gamiton ha personal nga interes ug diri kumpleto nga paggamit han kwarta. Tikang hini makikita naton nga may diri maupay nga naibubulig ini nga pangungutang ha gawas labi na nga waray danay sinisiring nga transparency." [Due to international policy which allows a country's leader to borrow certain monetary or financial resources from international banks to support the national needs, it is sometimes used for personal interest and inadequate usage. Because of these, we could see the detrimental aspect of "borrowing resource privilege" especially that transparency is mostly not observed.]
}

But these might not be an easy goal for those who are hoping for reform since the socalled global order helped Global North to become successful. It also enables them to shape national and international politics and the global economy. Even historical colonization belongs to this category (Khalil 2018). Most colonizers from 14th until the 20th century took advantage of less powerful nations in Asia and Africa who happen to be some of the poorest countries in the world today. Extraction and manipulation of colonized states were present back 
then. Participants openly cited the historical colonization of the nation as a demonstration that affluent countries are imbued with some negative obligation, one participant ruminated such stage when: "Amo ini an panahon kun diin usa ha $3 G$ s han mga mananakop amo an 'gold' ug an 'natural resources' han nasod. Hadto nga panahon hira an duro nga nakakatagamtan han dapat para ha aton amo yana kita it nagkukuri" [During this time, one of colonizers' 3Gs rationale was for "gold" or the "natural resources of the country." They have greatly taken advantage of the things which were absolutely for and from us; as a result, we are now suffering from that cause]. Thus, the flourishing way of living in developed nations, in some ways, cannot be considered a separate achievement because that is also an indirect by-product of exploitation and inequitable distribution of means. What is more, participant B managed to bring up the exploitation of the nation's wealth within the modern era:

\footnotetext{
"Diri la ha aton naglabay nga panahon nahitatabo ini, biskan yana nahitatabo la gihap ini. Kitaon ta nala it nahitatabo ha aton kadagatan, damo nga nasod it nag-aaragaw hini nga kun danay diri ginrirespto it aton pagkanasud, sugad man liwat hit iba nga kompanya tikang ha gawas nga nag-o-operate hin pagmimina." [The exploitation of natural resources is not only done during the period of colonialism; it is still going on today. For instance, in the case scenario of our maritime waters, several countries are struggling and contesting for the ownership of these seas while disregarding the sovereignty of the nation. Even the mining operation of some foreign companies is included in this list.]
}

Yet, it will be an immense mistake to ignore what is happening to people in poorer nations. If developed countries wanted to have a socially and politically stable world, then they ought to solve several social problems including terrorism, violence, and crime which are common results of extreme poverty. Social problems, as reported by participant C, more likely start with people's unemployment due to extreme poverty. "It kawaray trabaho in tungd hit kakurian hit kinabuhi kun diin napipiritan it iba nga mangawat ug sumakob ha diri maupay nga buhat sugad hit pagdodroga" [Unemployment is usually associated with the occurrence of great poverty which forces a person to enter into criminal acts such as robbery and illegal drugs involvement]. Pervasive inequalities, as scholars also pointed out, can pave the way to some series of social problems including the continual cycle of poverty that could also lead to the emergence of crime and violence. In a nutshell, the present global order, poverty, and crime seem to have a strong nexus that should not be overlooked.

Another form of negative duty's violation from wealthy states and supranational agencies is the insufficient and unsatisfactory implementation of equalities and equities principles enshrined in their institutions' goals and objectives. These are crucial points in attaining a progressive society and a preponderant attempt to fully furnish, at least above the minimum extent, everyone's human rights. As participant B said, "kumu usa nga tawo, katungdanan naton it pagpakaupay hit kada tagsa para hit mahimyang nga nasud ug kalibutan" [as human beings, we are implicated with the duty for promoting a peaceful and serene country and world, in general]. For Devetak et al. (2017), helping the least privileged is following the promotion of equal opportunity. Besides, it would be a mere printed text and hypocrisy on the part of the international agencies' founders who pretend to have high standards while neglecting adverse effects. Even more important, bringing the idea of justice into the global arena "necessarily requires global solutions, including the democratizing of the international realm" (Devetak et al. 2017, 292).

Global poverty is unmistakably a problem since the past and by regarding it as a manner of social concern, it attaches the human's obligation though it does not mean that we are doing this for the sake of duty. On the words of participant A with regards to this shared humanness: 
"Kinahanglan nga an kakurian ha bug-os nga kalibutan panginlabutan han ngatanan tungod nga ha uusa la kita nga kalibutan naukoy ngan nahinggok hin parehas nga hangin, kun sugad katungdanan naton nga buligan an mga tawo nga nag-uukoy ha makuri ngan pobrehanon nga kinabuhi." [Global poverty must be a social concern of humanity for we are only living in the same world and breathing the same air, therefore, we have an obligation to relieve people's lives who are experiencing and in the brink of extreme indigence.]

There is a responsibility to help the poor. Not to harm or impose suffering is not only applicable to the global poor but also us (as human beings).

\section{CONCLUSION}

The entire study was devised and directed towards the aspiration of understanding the bases of Global North's obligation in eradicating global impoverishment via the selected participants who are, in general terms, identified to be part of the huge picture in promoting social justice concerning the pervasiveness of poverty and must have a global awareness of the issue. Being a group of people who are encouraged and expected to be conversant, looking into their ideas would be useful, not as a means of justifying the claims that an affluent state is wholly responsible, rather for a thoughtful examination of one of the contentious cases in society. Moreover, it was a unanimous inference of the participants that responding to global poverty is a matter of negative obligation and social concern (of developed countries as a result of their involvement in an unjust and unequal world order). This is seen in the five identified themes from the study, namely: (1.) inequalities brought about by international order and organizations; (2.) socioeconomic gain from discriminatory advantage; (3.) poverty causes social problems; (4.) quality of living as an indication of progress; and (5.) we share and live in the same world. With these in mind, the palpability of research analysis was a manifestation of, if not a full grip, reasonable global perspectives, and cognizance of the participants on the problem.

\section{ACKNOWLEDGMENTS}

Initially, I would like to express my sincere gratitude and appreciation to my primary editor, Sir Jan Gresil Kahambing, for his immense knowledge, motivation, and patience. His guidance helped me throughout the study for a substantial outcome. I would also like to thank my family for their positive and moral support when I was writing and pursuing this research.

\section{REFERENCES}

Abumere, F.A. 2015. Different perspectives on global justice: A fusion of horizons. PhD thesis, LUISS, Italy.

Boot, E. 2014. Subsistence needs and individual duties. Theoria \& Praxis: International Journal of Interdisciplinary Thought 2 (1): 1-22.

Bradshaw, C., S. Atkinson, and O. Doody. 2017. Employing a qualitative description approach in health care research. Global Qualitative Nursing Research 4: 1-8.

Braun, V., and V. Clarke. 2006. Using thematic analysis in psychology. Qualitative Research in Psychology 3 (2): 77-101.

British Columbia Teachers' Federation. 2010. Poverty and education: A teacher's perspective. http://www.bctf.ca/uploadedFiles/Public/Publications/ResearchReports/2012-EI-01.pdf (accessed March 20, 2020) 
Canadian Teachers' Federation. 2009. Supporting Education...Building Canada: Child Poverty and Schools. https://www.ctf-fce.ca/ResearchLibrary/FINAL_Hilldayleavebehind_eng.pdf (accessed March 20, 2020)

Chossudovsky, M. 2003. The globalization of poverty and the new world order. 2nd edition. Pincourt, QC, Canada: Global Research, Center for Research on Globalization

Chossudovsky, M. 2020. World Bank. https://www.britannica.com/topic/World-Bank (accessed March 19, 2020)

Dalberis, R. 2015. Extreme levels of poverty and inequality may lead to equally high levels of social conflict and crime. Master's thesis, City College of New York.

Daskal, S. 2013. Confining Pogge's analysis of global poverty to genuinely negative duties. Ethical Theory and Moral Practice 16 (2): 369-391.

Devetak, R., J. George, and S. Percy. 2017. An introduction to international relations. 3rd edition. Cambridge, UK: Cambridge University Press

Dietzel, A. 2018. Introducing Global Justice in International Relations Theory. In International Relations Theory, eds. Stephen McGlinchey, Rosie Walters \& Christian Scheinpflug. USA: E-International Relations Publishing.

Donald, A., and E. Mottershaw. 2009. Poverty, inequality and human rights. https://www.jrf.org.uk/report/poverty-inequality-and-human-rights (accessed March 19, 2020)

Etikan, I., S.A. Musa, and R.S. Alkassim. 2015. Comparison of Convenience Sampling and Purposive Sampling. American Journal of Theoretical and Applied Statistics 5 (1): 1-4.

Fan, W. 2009. Ethical problems in connection with world poverty. Master's thesis, Lingnan University.

Finance Center for South-South Cooperation. n.d. Global south countries. http://www.fcssc.org/en/partnership_program/south_south_countries (accessed April 20, 2020)

Flynn, N. 2014. The Poverty Priority: A secondary school geography teaching resource for Years 7 to 10. Australia: One World Centre

Fusch, P., and L. Ness. 2015. Are We There Yet? Data Saturation in Qualitative Research. The Qualitative Report 20 (9): 1408-1416.

Gairdner, F.T. 2009. A Defence of Thomas Pogge's Argument for a Minimally Just Institutional Order. Master's thesis, Queen's University.

Hall, R., and L.A. Harvey. 2018. Qualitative research provides insights into the experiences and perspectives of people with spinal cord injuries and those involved in their care. Spinal Cord 56 (6): 527.

Hickel, J. 2018. Jason Hickel: "We can end poverty by changing the rules of the global economy".https://ideas4development.org/en/end-poverty-changing-rules-economy/ (accessed April 17, 2020)

Jamshed, S. 2014. Qualitative research method-interviewing and observation. Journal of Basic and Clinical Pharmacy 5 (4): 87-88.

Khalil, S. 2018. Ethics Beyond Borders: The nature of our responsibility towards the refugee population. PhD thesis, Wellesley College.

Kriegstein, H. 2009. A bad argument for a good case: Pogge on poverty and negative duties. Saga: Rev. Estud. Filos 10 (20): 57-68.

Lasco, R., F. Pulhin, P.A. Jaranilla-sanchez, R.J. Delfino, R. Gerpacio, and K. Garcia. 2009. Mainstreaming adaptation in developing countries: The case of the Philippines, Climate and Development 1 (2): 130-146

Lichtenberg, J. 2010. Negative duties, positive duties, and the "new harms". The University of Chicago Press Journals 120 (3): 557-578. 
Neuendorf, K. A. 2019. Content analysis and thematic analysis. In Advanced research methods for applied psychologists: Design, analysis and reporting, ed. P. Brough, 211-223. New York: Routledge.

Nwaneri, N.V. 2017. Human rights and global justice: A normative critique of some Rawlsian approaches. $\mathrm{PhD}$ thesis, Loyola University Chicago.

Palmer, K. 2015. Effects of poverty on the brains of children and effective teaching strategies to meet their specific needs. Master's thesis, State University of New York.

Parcon, I.C. 2017. Thomas Pogge and the limits of negative duty. Kritike 11 (1): 218-234.

Parrett, W., and K. Budge. 2015. What Can Schools Do to Address Poverty? https://www.edutopia.org/blog/what-can-schools-do-to-address-poverty-williamparrettkathleen-budge (accessed March 19, 2020)

Pathak V., B. Jena, and S. Kalra. 2013. Qualitative research. Perspectives in Clinical Research $4(3): 192$.

Pertiwi, M. 2018. The Border of Responsibilities in Global Distribution of Aid: Ethical Issues and Challenges in Practices. Global \& Strategies 12 (2): 107-118.

Pierik, R. 2013. Do We Have a Negative Duty Towards the Global Poor? Thomas Pogge on Global Justice. In Spheres of Global Justice, ed. Jean-Christophe Merle, 595610.Dordrecht: Springer.

Pogge, T. 2002. World Poverty and Human Rights. Cambridge, UK: Polity Press

Pogge, T. 2005. Real world justice. The Journal of Ethics 9 (1-2): 29-53.

Pogge, T. 2005. The first UN millennium development goal: A cause for celebration? In Real world justice: Grounds, principles, human rights, and social institutions, eds. Andreas Follesdal \& Thomas Pogge, 317-338. Dordrecht, The Netherlands: Springer.

Pogge, T. 2007. Severe poverty as a human rights violation. In Freedom from poverty as a human right: Who owes what to the very poor?, ed. Thomas Pogge, 11-54. New York: Oxford University Press.

Quejada, A., and R. Orale. 2018. Lived experiences of elementary teachers in a remote school in Samar, Philippines. Journal of Academic Research 3 (3): 1-13.

Sonderholm, J. 2012. Thomas Pogge on global justice and world poverty: A review essay. Analytic Philosophy 53 (4): 366-391.

Spauwen, N. 2012. Responsible Citizens in a Global Era: Individual Agents as Constitutive of Justice within a Basic Structure. Master's thesis, Utrecht University.

Steiner, M. 1996. Developing the global teacher: Theory and practice in initial teacher education. London, Great Britain: Trentham Books

Urbano, R. 2011. Global justice and the plight of Filipino domestic migrant workers. Journal of Asian and African Studies 47 (6): 605-619.

Valencia, C. 2018. Philippines improves ranking in WEF's Inclusive Development Index. http://industry.gov.ph/philippines-improves-ranking-wefs-inclusive-developmentindex/ (accessed April 20, 2020)

Vongalis, A. 2004. Global education policy directives: Impact on teachers from the North and South. International Education Journal 5 (4): 488-501.

Weidel, T. 2012. Beyond utility, rights, and care: An alternative approach to global Poverty. $\mathrm{PhD}$ thesis, Loyola University Chicago.

\section{NIÑOVAL F. PACAOL}

Leyte Normal University

Paterno St, Downtown, Tacloban City,

6500 Leyte, Philippines

*Corresponding author: ninoval.pacao105@gmail.com 